\title{
I Have Faith in Thee, Lord: Criticism of Religion and Child Abuse in the Video Game the Binding of Isaac
}

\author{
Frank G. Bosman ${ }^{1, *}$ and Archibald L. H. M. van Wieringen ${ }^{2}$ \\ 1 Department of Systematic Theology and Philosophy, Tilburg University, 5037 AB Tilburg, The Netherlands \\ 2 Department of Biblical Sciences and Church History, Tilburg University, 5037 AB Tilburg, The Netherlands; \\ A.L.H.M.vanWieringen@TilburgUniversity.edu \\ * Correspondence: F.G.Bosman@uvt.nl or A.L.H.M.vanWieringen@uvt.nl
}

Received: 26 March 2018; Accepted: 12 April 2018; Published: 16 April 2018

check for updates

\begin{abstract}
The game The Binding of Isaac is an excellent example of a game that incorporates criticism of religion. Isaac is a roguelike dungeon crawler with randomly generated dungeons. Both from the perspective of narrative and of game design, McMillen built The Binding of Isaac around the Biblical story of Genesis 22:1-19, which has the same name in Jewish and Christian tradition, but he placed it in a modern-day setting in which a young boy is endangered by a mentally disturbed mother who hears "voices from above" that instruct her to sacrifice her only child. Multiple critical references to Christianity can be found in addition to the narrative: hostile embodiments of the seven deadly sins, rosaries, Bibles, and crucifixes, and unlockable characters, such as Mary Magdalene, Judas Iscariot, Samson, and Cain, who are all depicted negatively in both Jewish and Christian traditions. McMillen's inspiration came from his own experiences with his family, which was made up of both Catholics and born-again Christians. The game describes both the dark creativity and the mental and physical abuse associated with religion. In this article, we analyse the narrative of The Binding of Isaac by performing an intertextual comparison with the Biblical narrative of Genesis 22:1-19. We then analyse the three-fold narrative structure of the game which enhances and nuances the criticism the game directs at religion.
\end{abstract}

Keywords: studies; Bible; theology; Isaac; Catholicism; criticism of religion; child abuse

“To prove your love and devotion, I require a sacrifice. Your son Isaac will be this sacrifice. Go into his room and end his life as an offering to me, to prove that you love me above all else!"

The quotation above is not taken from the book of Genesis, as careful readers will already have understood, but it resembles Gen 22:2 very closely. "Take your son, your only son Isaac, whom you love, and go to the land of Moriah; and offer him there as a burnt offering... " The verse is part of the larger narrative on Abraham, who seems willing to offer his only son to God without asking any questions, simply because God asked him to do so. The passage, known in the three monotheistic religions as "the Binding of Isaac" (Caspi and Greene 2007), has been heavily debated in many theological contexts, but has also been used to bluntly criticise the supposedly inherently violent nature of institutionalised religion in general, and of monotheism in particular. In his God Delusion (Dawkins 2006, p. 242), Richard Dawkins put it as follows:

A modern moralist cannot help but wonder how a child could ever recover from such psychological trauma. By the standards of modern morality, this disgraceful story is an example simultaneously of child abuse, bullying in two asymmetrical power relationships, and the first recorded use of the Nuremberg defence: 'I was only obeying orders.' Yet the legend is one of the great foundational myths of all three monotheistic religions. 
The opening quote of this article is not taken from Genesis, but from the prologue of The Binding of Isaac, a digital game by independent game developer Edmund McMillen (2011). Both the game itself and its prologue/epilogue depend strongly on Catholicism in general and on the Biblical story of the binding of Isaac in particular. The abundant use of rosaries, Bibles, crucifixes, holy water, and the like suggests this, as does the prologue/epilogue that closely resembles the Biblical narrative, but deviates from it on a number of key points, even apart from the contemporary staging.

In the game, Isaac's mother is presented as a theomanic single mom, who hears "voices from above" urging her to "save" her young son Isaac who has become "corrupted by sin". Ultimately, the voice from above commands her to kill her son to "prove that you love me above all else" an injunction which the mother immediately prepares to carry out. Isaac, seeing his mother's madness, flees into an unknown "abyss" he discovers under a rug in his bedroom.

The game shows what Isaac finds in this abyss-innumerable dangers, insects, and abominations-until he succeeds in killing the "Heart of Mother". Victory brings the player back to the epilogue, where his mother's deadly blow is stopped by a Bible that falls onto her head from a shelf. However, multiple alternative endings found throughout the game suggest that Isaac did not meet with a happy end, pointing as they do to several forms of child abuse, many of them interlaced with religious symbols and notions.

In this article, we examine McMillen's game by establishing the intertextual relationship (Kristeva 1980) between the Genesis narrative (the arche-text) and the game The Binding of Isaac (the feno-text). Intertextuality is a synchronic approach, focussing on the characteristics texts have in common. To establish this relationship, we discuss both texts, first the Biblical text (Section 1), then the game text (Section 2), from a synchronic point of view, with special attention to their semantics and to the various roles of the characters and the text-immanent author and reader. In the description and interpretation of the Bible text, we differentiate between the semantics of the text and the communication in the text.

In the description and interpretation of the game text, we differentiate among five different narratological levels: the "pre-text" of McMillen's religious inspiration (Section 2.1); the prologue/epilogue (Section 2.2); the game in the strict sense, which takes place between the prologue and epilogue (Section 2.3); the post-prologue/epilogue (Section 2.4); and the multiple endings found throughout the game (Section 2.5). Finally, we propose a reconstruction of the "real" story of The Binding of Isaac, incorporating the different intertextual relationships between the two texts (Section 3).

We regard games as "digital (interactive), playable (narrative) texts" (Bosman 2016) in this article. As text, a video game is an object of interpretation. As narrative, it communicates meaning. As game, it is playable. As digital medium, it is interactive. Treating video games as playable texts and using a gamer-immanent approach (Heidbrink et al. 2015), we have performed a close reading of the video game, including its remake (called Rebirth) and its two expansion packs (Afterbirth and Afterbirth+), by playing the game and all its versions ourselves several times.

\section{The Arche-Text: The Genesis Narrative}

Genesis 22:1-19 tells the story of God who tests Abraham. God asks Abraham to sacrifice his son Isaac. Obeying God's command, Abraham goes to the mountains of Moriah. Isaac goes with him. On the mountain, Abraham builds an altar and prepares everything for the sacrifice. However, at the very moment he is about to kill Isaac with a knife, God's angel intervenes. Instead of the son, he sacrifices a ram. The mountain becomes a sign about the mountain of the Lord. God's angel acts for a second time. He praises Abraham and promises him numerous offspring. The story concludes with Abraham returning from the mountain.

The narrative text of Genesis 22:1-19 has been discussed extensively over the centuries. The diachronic exegetical discussion, e.g., concerning the Yahwistic source as an older edition of the text (see especially: Westermann 1981, pp. 429-47), is not important for our research into the 
intertextual, i.e., synchronic, relationship between the biblical text (arche-text) and the video game (feno-text). Therefore, we focus on a synchronic analysis first.

The narrative contains two semantic themes (Van Wieringen 1995, pp. 293-99). The first is about testing, expressed mainly with the verb to test (נסה), the second is about the cult, expressed by using

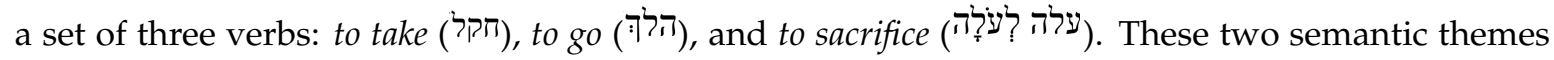
are intertwined.

The narrative opens with the first semantic theme. After these things, God tested Abraham (verse 1). This test appears to consist of a threefold instruction (verse 2). Abraham appears to be very willing to implement it, because the first thing he does, early in the morning, is to saddle his donkey (verse 3), something one normally does at the moment of departure. However, the text of the narrative mentions the first two elements of the instruction three times, but does not mention the third element, to sacrifice.

In verse 3, Abraham takes Isaac and Abraham goes. However, instead of sacrificing, verse 4 has Abraham seeing. Abraham's eyes are focused on the place of the sacrifice, i.e., the cultic location. In verse 6, Abraham takes the wood required for the sacrifice, and places it upon Isaac. He also takes the fire and the knife in his own hand, and he goes with Isaac. There is no reference to sacrificing.

The activities of taking and going are mentioned again in the verses $8 \mathrm{~b}-10$. Abraham and Isaac are going to the place of the sacrifice. When they have reached this place, Abraham takes the knife, instead of Isaac. This activity of taking the knife, which did not appear in God's instruction, is recounted in slow motion. Again, the activity of sacrificing is absent. Instead of sacrificing, Abraham is about to cut Isaac's throat, which was not part of God's instruction either. Fortunately, the angel of the Lord intervenes to prevent Isaac from being killed (the verses 11-12).

Verses 11-12 not only stop Abraham from improperly implementing the instruction, but also reintroduce the theme of the test. The angel of the Lord solemnly declares that Abraham has passed the test.

Verses 13-14a take up the semantic theme of the sacrifice again and mention two aspects. First, the Lord's command is properly implemented. Abraham goes, he takes the ram, instead of his son, and sacrifices it. Second, in addition to this set of three activities, the activity of seeing, which was already present in the text as a substitute for the activity of sacrificing, is mentioned twice as an inclusion: Abraham sees the ram (verse 13a) and, unto this very day, people say that the Lord sees.

The theme of the test is mentioned one last time before the final verse 19. Once again, the angel observes that Abraham has passed the test, but this time several future promises accompany the statement.

The semantic theme of the test predominates in the reception of Genesis 22:1-19 (Agus 1988; Rowley 2015). The test is interpreted as inviting unquestioning obedience to God. Just do what God asks you, even if he asks you to sacrifice your own son.

However, the complex semantic themes in the text demonstrate that this interpretation is restrictive, and the complex communicative structure makes it clear that it is inadequate (Van Wieringen 1995, pp. 300-4). In verse 5, Abraham says to his servants that "we", i.e., Abraham and Isaac, will return from the mountain. Was Abraham telling a white lie? Or did he already know that Isaac would not be sacrificed? Verse 8 contains the same communicative tension. Abraham says to his son that God will provide the ram for the sacrifice. Was Abraham telling a white lie again? Or did he already know that Isaac would not be sacrificed? Ultimately, Isaac is not sacrificed.

According to the text of the narrative, there must have been a communication between the Lord and Abraham which is not mentioned in the text itself. In verse 2, the Lord says that he will point out the mountain of the sacrifice to Abraham, and in verse 4 Abraham actually sees this mountain. If this information really was about the mountain of the sacrifice, it may have been more than just information of a location.

What about Isaac? In verse 7, he asks his father a question about the sacrifice. The question expresses his surprise that everything they need for the sacrifice is there except the ram. However, Isaac does not mention the knife in his question. The knife seems to be absent in Isaac's perception-even when Abraham takes the knife to cut his throat. The final verse 19 is surprising. It says that Abraham returns to the servants, but does not mention Isaac. Where is Isaac, who has been given away to God? Is he still on the mountain? These questions are (and remain) unanswered by the text. 
One aspect of the diachronic analyses of Genesis 22:1-19 might be of importance here. As the Sitz im Leben, many exegetes used to believe that the text was discussing child sacrifices in ancient Canaan. The narration's purpose would be to make clear that child sacrifices should be rejected. God seems to ask for it, but in fact he does not: he opens the religious form of obedience and cult instead. In fact, we now know that child sacrifices were not common in ancient Canaan, and perhaps only in situations of severe hostile threat. In the modern reception of Genesis 22:1-19, the idea of the God of Israel not asking for child sacrifices, in contrast to the idols of Canaan, is still present (see the recent discussion in (Bauer 2017). This view on child sacrifices probably inspired McMillen for this video game in which child abuse is central, as we will explain in detail below.

The reception of Genesis 22:1-19 in the Jewish and Christian tradition is very complex (see also: Lenzen 2003). For our intertextual examination of the arche- and feno-text, it is important to notice that both traditions have their own specific accent as expressed in the name of this biblical passage. In the Jewish, i.e., Rabbinic, tradition, the narrative is known as "the Binding of Isaac", in Hebrew

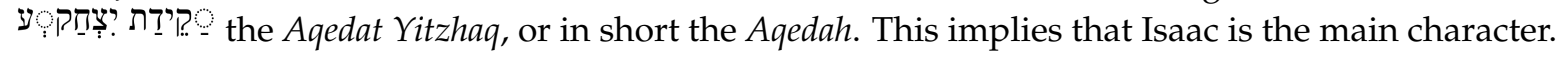
$\mathrm{He}$ is in focus. In the Christian tradition, the narrative is known as the Sacrifice of Abraham, which implies that Abraham is the main character. In the Binding of Isaac, Isaac is the main character, whereas the character of Abraham is not prominent, which implies that, in its reception of the arche-text, the Binding of Isaac is closer to the Jewish than the Christian tradition.

\section{The Feno-Text: The Game Narrative}

The Binding of Isaac is a roguelike top-down dungeon crawler, designed by Edmund McMillen (designer) and Florian Himsl (programmer). Directly inspired by the classic 1986 NES game The Legend of Zelda (McMillen 2012), the game connects chamber to chamber, incorporating procedurally-generated levels that particularly enhance and stimulate multiple playthroughs, for which the player is rewarded by unlockable characters, passive items, or achievements. The gamer must first defeat all the monsters in a given chamber before he can enter the next. The player controls a naked figure, Isaac, whose primary weapon is his ability to "shoot" tears at his enemies. Helpful items can be found and active and passive abilities can be unlocked during the game to add to Isaac's armoury. When Isaac's life reaches zero, the player is forced to restart the game from the beginning.

The original The Binding of Isaac (BoI) was released in 2011 for Windows, and later ported to OS $X$ and Linux. In 2012, the first expansion pack was released, entitled Wrath of the Lamb, a reference to the biblical book of Revelation (see especially: Rev 6: 16). In 2014, a remake of the original BoI was released, dubbed Rebirth, developed and published by Nicalis for Windows, OSX, Linux, PlayStation 4, and PlayStation Vita, and later also for Wii U, New Nintendo 3DS and Switch, Xbox One, and iOS (McMillen 2014). In 2015, two new expansions were released, Afterbirth (McMillen 2015a) and Afterbirth+ (McMillen 2015b), introducing new items, enemies, bosses, and endings. The game was applauded by critics and fans alike, obtaining a score of 84 on Metacritic.com. A list of all versions and expansions is listed below (Table 1).

Table 1. Versions of the Binding of Isaac.

\begin{tabular}{|c|c|c|}
\hline Ab. & Expansions & Release \\
\hline BoI & The Binding of Isaac & 2011 \\
\hline WoL & Wrath of the Lamb & 2012 \\
\hline BoR & The Binding of Isaac: Rebirth & 2014 \\
\hline BoA & Afterbirth & 2015 \\
\hline BoAt & Afterbirth+ & 2015 \\
\hline
\end{tabular}


Five different narratological levels can be distinguished in The Binding of Isaac: (1) McMillen's inspiration; (2) the prologue/epilogue; (3) the game in the strict sense, which takes place between prologue and epilogue; (4) the post-prologue/epilogue; and (5) the various endings of the game.

\subsection{Pre-Text: McMillan's Inspiration}

In various online articles and interviews, the designer McMillen has quite clearly articulated the religious inspiration for The Binding of Isaac (Holmes 2011; Jagielski 2011; Smith 2011; McMillen 2012). He describes his religious upbringing as a hybrid between Roman Catholicism and born-again Christianity, both sides contributing to the creation of The Binding of Isaac:

I grew up in a religious family. My mom's side is Catholic, and my dad's side is born-again Christians. The Catholic side had this very ritualistic belief system: My grandma could essentially cast spells of safe passage if we went on trips, for example, and we would light candles and pray for loved ones to find their way out of purgatory, and drink and eat the body and blood of our saviour to be abolished of mortal sin. As a child growing up with this, I honestly thought it was very neat, very creative and inspiring. It's not hard to look at my work and see that most of the themes of violence actually come from my Catholic upbringing, and in a lot of ways I loved that aspect of our religion. Sadly, the other side of my family was a bit more harsh in their views on the Bible; I was many times told I was going to hell for playing Dungeons \& Dragons and Magic: The Gathering (in fact, they took my $\mathrm{MtG}$ cards away from me), and generally condemned me for my sins. (McMillen 2012)

McMillen includes dark and adult content most other game developers would rather avoid or neglect.

A lot of the content in Isaac is extremely dark and adult. It touches on aspects of child abuse, gender identity, infanticide, neglect, suicide, abortion, and how religion might negatively affect a child, which are topics most games would avoid. (McMillen 2012)

BoI's major theme was indeed inspired by the Biblical narrative of the same name.

The games story was inspired heavily from a story in the bible called the Binding of Isaac, where God asks Abraham to sacrifice his son Isaac to Him to prove his devotion. (Jagielski 2011)

McMillen wanted to reflect his own dualistic experience of religion, in showing both its positive and negative effects. On the one hand, the self-hatred and isolation McMillen experienced in his youth, but on the other also the creative openness that biblical passages have that allow their readers to interpret them each in their own way. The multiple endings that players can reach in BoI are a reference to this openness:

The Bible is a very good, creatively written book, and one of my favourite aspects of it is how so many people can find different meanings in one passage. I wanted Isaac to have this in its story as well, which is why the game's final ending(s) have many possible interpretations. (McMillen 2012)

McMillen's heavy use of religious phrases, artefacts, items, and images is, therefore, not accidental to the game, but expresses the developer's inspiration and intentions. Every interpretation of the game's content should take this religious inspiration into consideration.

\subsection{The Prologue/Epilogue Narratives}

The prologue and epilogue appear as simple pencil drawings on a desk (later identified as Isaac's). The tip of a small finger is seen in the bottom left corner of the screen (also later identified as Isaac's) next to a half-visible pencil. A fly can be seen hovering over the pictures, one of the main 
simple enemies the player will encounter in the game. The title, "The Binding of Isaac", appears in handwritten letters together with a small simplified version of Isaac drawn below.

Isaac and his mother are introduced to the gamer as they stand beside each other and smile. Isaac is small compared to his mother, indicating he is still in pre-puberty. Their names are written beside them: "Isaac" and "Mom". The narrator recounts:

Isaac and his mother lived alone in a small house on a hill. Isaac kept to himself, drawing pictures and playing with his toys as his mom watched Christian broadcasts on the television. Life was simple, and they were both happy. That was, until the day Isaac's mom heard a voice from above.

We see a drawing that shows a simple house as drawn by a young child: one door, one window, and a tree and bushes beside it. Isaac is shown sitting on the floor beside mom's couch. He is surrounded by two dolls (in silhouette) and is working on two separate drawings with undistinguishable lines and figures. Isaac's mother smiles as she watches over him from the couch. She holds the television remote control in her right hand, the television itself stands before her. Then she suddenly appears shocked by something only she notices. Lines blinking from above indicate that a voice is coming "from above". The narrator says,

"Your son has become corrupted by sin! He needs to be saved!"-_I will do my best to save him, my Lord," Isaac's mother replied rushing into Isaac's room removing all that was evil from his life.

We see Isaac's mother dashing into Isaac's room, tearing down a poster from the wall, and stuffing Isaac's belongings into a box she holds under her arm. She has a frantic expression. Isaac is shown with a doll and a handheld computer in his hands, which both disappear as a sign of his mother's rigorous devotion to the assignment she has been given. Eventually, even his clothes disappear, and Isaac is naked. Again, we see Isaac's mother on the couch, the remote control in her hand, but Isaac is standing naked and without toys. The narrator recounts,

Again, the voice called to her: "Isaac's soul is still corrupt! He needs to be cut off from all that is evil in this world and confess his sins." - "I will follow your instructions, Lord. I have faith in thee," Isaac's mother replied as she locked Isaac away in his room, away from the evils of the world.

We see how Isaac is thrown into his own room. The door closes behind him and Isaac lies naked on the ground. Again, we see Isaac's mother on the couch, but now with a crazy look on her face: one eye is larger than the other one and there is a contorted smile on her mouth. For the third time a voice rings out from above, which only she can apparently hear. Her old smile returns when she replies to the voice,

One last time, Isaac's mom heard the voice of God calling to her: "You have done as I asked, but I still question your devotion to me. To prove your faith, I will ask one more thing of you."- “Yes, Lord. Anything," Isaac's mother begged. "To prove your love and devotion, I require a sacrifice. Your son Isaac will be this sacrifice. Go into his room and end his life as an offering to me, to prove that you love me above all else!"—_Yes, Lord," she replied grabbing a butcher's knife from the kitchen.

Isaac's mother is seen with a butcher's knife in her hand, looking grimly at the closed door of Isaac's room. Isaac is looking through a crack in the door, sees what his mother is doing, and understands the consequences it will have for him. We see Isaac sitting on the floor, shaking with fear. He tries to find a way out of his room, but the door is locked and iron bars block his only window.

"Isaac, watching through a crack in the door trembled in fear. Scrambling around his room to find a hiding place he noticed a trapdoor to the basement, hidden under his rug." 
Isaac finds a hidden trapdoor under the rug in his room. Neither the rug, nor the trapdoor were visible in earlier scenes, as if they did not exist then. He opens the hatch, while Isaac's mother bursts through the door, brandishing the knife in her hand.

"Without hesitation, he flung open the hatch just as his mother burst through his door and threw himself down into the unknown depths below."

Isaac jumps through the hatch and lands in an unknown room, while light from above shines on him. There is no further trace of his mother.

Although this is not the end of the prologue, we leave the scene for the time being and return to it in Section 2.5. Isaac and his mother are living together in their home. Whereas everything is all right at the beginning, things quickly get out of hand when Isaac's mother starts to "hear voices". As we have seen before, McMillen is undoubtedly referring to the mother's madness, not her possible piety. Isaac's theomanic mother wants to kill her son because she thinks she has received a divine commandment that she must do so, and Isaac is barely able to escape by entering a previously unknown doorway that leads to a space under the house.

The epilogue takes the narrative almost directly from where the prologue ends. Isaac is still in his room, standing fearfully in a corner as he tries—in vain — to escape his murderous mother. The narrator:

Isaac was cornered. His mother, fuelled with the desire to serve her god, was bearing down on Isaac. "I will do as I'm told, my lord. I love you above all else", Isaac's mother repeated to herself.

Isaac's mother is towering above him, her knife ready to strike. The look on her face is totally manic. Isaac is lying on the ground, his eyes closed, with his arms around his legs, in the foetal position. His mother is ready to strike. We can now see a bookshelf with a book and a vase on it that were not there in earlier scenes.

"This was the end of the line for Isaac, his mother was far too strong for him. But just as he accepted his fate, god intervened, sending an angel down from above to stop his mother's hand. And just like that, it was over."

The book on the shelf suddenly becomes adorned with the Christian sign of the cross, indicating that it is a Bible. As soon as the narrator speaks about God's intervention, the book mysteriously falls or is thrown onto the mother's head, knocking her out. As she lies stretched out on the floor, either dead or unconscious, Isaac jumps onto her body, holding up his hands in the air in a victory pose.

Although this is not the end of the epilogue, we will stop at this point to better interpret the prologue and epilogue as a (wondrous) tale about a young son and his theomanic mother, whom he defeats with the help of divine intervention. However, the end of the prologue and the beginning of the epilogue do not match each other perfectly: the prologue ends with Isaac jumping down "into the depth" and it gives way narratologically to the beginning of the game itself, while the epilogue seems to be unaware of Isaac's successful escape attempt. Ultimately, Isaac is triumphant: he defeats his mother and saves his own life. However, this rather simplistic but religion-critical interpretation is challenged by the other narratological levels, which we discuss below.

\subsection{The Game Narrative}

The game itself (excluding for the moment the (post)prologue/epilogue and the various alternative endings) is littered with references to the Christian tradition in general and Roman Catholicism in particular. Ludologically, the player's only goal is to work his or her way through different levels in six different chapters. Narratologically, the player-Isaac-delves deeper and deeper into the abyss under the rug in his bedroom, until he is finally able to slay his deranged mother, who is depicted in a dehumanized form, as a real monster who needs to be defeated. The different chapters-Basement/Cellar, Caves/Catacombs, Depths/Necropolis, Cathedral/Sheol, and Chest/Dark Room - evoke the idea of descent in general, and in particular the psychological notion 
of descending into one's own soul in the search for deeper personal understanding, in combination with the Christian notion of hell and the underworld (the Hebrew/Jewish sheol) as a place where the wicked are punished.

As Isaac flees his theomanic mother, who is clearly inspired by the figure of Abraham in the Genesis narrative, we see numerous references to Christian lore. It is not necessary to give an exhaustive list of all items and entities that contain religious references; a few examples will suffice. The category of "active collectibles" (items that can be activated for bonuses) contains Christian objects like the Bible (which instantly kills the Mother Monster at the end of the game), the Book of Revelation (increases chance of finding special devil/angel rooms in the chapters), and the Dead Sea Scrolls (randomly activated item).

However, there are also numerous references to satanic lore, another one of McMillen's (2012) sources of inspiration. The designer has spoken about the "witch hunt" by conservative Christians in the 1980s against everything considered non-Christian, and the categorical labelling of such elements as "Satanist". Thus, there is the Book of Belial (the third book of The Satanic Bible by Anton LaVey, 1969), the Book of Secrets (a compilation of technical and medical recipes and magical formulas used in Wiccan circles), the Book of Shadows (ditto), the Necronomicon (H.P. Lovecraft's fictional grimoire), and the Book of Sin.

The category of "passive collectibles" (items that provide automatically applied bonuses) also contains the same two sources of inspiration. On the one hand, there is the "Blood of the Martyr" (a crown of thorns worn by Jesus according to the Biblical narratives), a "cat-o-nine-tails" (an implement similar to that used to flog Jesus), a "halo" (with which Catholic saints are traditionally depicted), "Guardian Angel", "Seraphim" (a certain group of angels from Christian lore), the "Eucharist", "Jacob's ladder" (from Gen. 28:12), a "rosary", "holy water", Longinus" spear (also known as the "Spear of Destiny") and a "Holy Grail". On the other hand, we find "Abaddon" (a pentagram), a "Ouija board", "Judas' Shadow", "leprosy", "Lord of the Pit" (inverted cross), "Succubus" (male demon) and the "Eye of Belial" (demon from the Old Testament).

These references can be found even in the major bosses that the player encounters. Thus, there are the seven deadly sins-Envy, Gluttony, Wrath, Pride, Lust, Greed, and Sloth—which take the form of Isaac himself, indicating the psychological nature of these sins. We find "the Harbingers" from the Book of Revelation, in multiple variations: Famine, Pestilence, War, Death, Conquest, and "the Headless Horseman". Other bosses are clearly physically inspired by medieval demons, including horns and inverted crosses, called "the Dark One", "the Adversary" (from the Biblical book of Job), "The Fallen", and "the Duke of Flies" (a reference to the figure of Beelzebub, a Philistine deity from the Old Testament, dismissed by Jesus in the New Testament as "the Lord of the Flies").

Finally, there are the unlockable characters (see Table 2), who are either devils, or "unlucky figures" from the Old and New Testament narratives, unjustly condemned in the Christian tradition.

Table 2. Unlockable characters in The Binding of Isaac.

\begin{tabular}{cccc}
\hline Character & BoI/BoR & BoA & BoA+ \\
\hline ??? & X & & \\
Azazel & X & & \\
Cain & X & & \\
Eden & X & & \\
Eve & $\mathrm{X}$ & & \\
Isaac & $\mathrm{X}$ & & \\
Judas & $\mathrm{X}$ & & \\
Lazarus & $\mathrm{X}$ & & \\
Lost, the & $\mathrm{X}$ & & \\
Magdalene & $\mathrm{X}$ & & \\
Samson & $\mathrm{X}$ & & \\
Keeper & & $\mathrm{X}$ & \\
Lilith & & $\mathrm{X}$ & \\
Apollyon & & & $\mathrm{X}$ \\
\hline
\end{tabular}

Caption text: An overview of unlockable characters in various versions of the Binding of Isaac (see also Table 1). $<? ? ?>$ indicates the name of an unlockable character in the game. 
Unlockable characters can be used by the player to replay the game in another avatar, which usually not only differs aesthetically from the standard one, but is usually granted a number of perks or disadvantages.

Most of the unlockable characters are derived from the Bible. Together with his brother Abel, Cain is the main character in the story of Gen 4:1-16. Cain is the villain who kills his brother. Sacrifice plays an important role in this story. God accepts Abel's sacrifice, but rejects that of Cain. The dominant interpretation in the reception of this biblical narrative is that Cain did not sacrifice the best of his flock, whereas Abel offered God the best fruits of the land. Because Cain did not offer the best he had God does not love him, and Abel falls victim to the ensuing quarrel between God and Cain. However, this idea is not mentioned in the text at all. The narratological plot of the biblical account points in a different direction: the problem is that there is no communication with Abel. Cain does not speak to his brother. By denying him all communication, Cain has already killed Abel, as it were, before the actual murder. In the Jewish Testament of Abraham (1st/2nd century), Abel is portrayed as a sun-like angel (Van der Toorn et al. 1999, p. 2).

The unlockable character Eden is named after the Garden of Eden, the décor of the biblical stories of Genesis 2-3. God entrusts the newly created humans with the care of the garden. They are free to do anything they want, except to eat from the tree of good and evil. They nevertheless do just that and suddenly becomes aware of their nakedness. The reception of these stories has more often than not held the woman responsible for eating from the forbidden tree (Tischler 2009, pp. 13-23). This could be the reason that Eden is a female unlockable character. In the Romantic area, the loss of innocence was seen as the loss of childlike innocence. In the videogame, Isaac is naked on all narratological levels. Child abuse can be regarded as a loss of innocence. This loss is not caused by the child's own sins. It is caused by the sins of his parents. In a way, the child is the victim of the primordial sin, i.e., a sin committed by a parent-or by his first forefathers in the Garden of Eden in Genesis 3.

Eve is regarded as the first human who disobeyed God (Gen 3). Mary Magdalene, although she was the first human witness of the risen Christ (John 20), is erroneously regarded in the Christian tradition as a converted prostitute (John 8) who was possessed by "seven demons" (Mark 16:9). Judas, of course, is the discipline who betrayed Jesus for thirty pieces of silver (Mat 26:15), after which he was overcome by guilt and committed suicide (Mat 27:5), thus burdening his soul even more. Samson is the main character in Judges 13-16. He is famous because of his strength: he tears a lion to pieces and defeats an entire army of enemies on his own. He falls in love with Delilah, who overpowers him by discovering his secret. In certain Christian traditions, Delilah is interpreted as Satan, who tests Samson (Caesarius of Arles, 5th/6th century).

Lazarus is a New Testament figure, a friend of Jesus. After Lazarus's death, Jesus comes to Bethany, the place where Lazarus lived, and raises him from the dead by telling him to come out of the grave. After his resurrection, Lazarus led a Christian life. In the Eastern tradition he became the first bishop of Kition (Larnaka) on Cyprus; in the Western tradition he became the first bishop of Marseille in France. Some traditions say that Lazarus never once smiled or laughed during the first thirty years after being raised from the dead, because he had seen the unredeemed souls in the netherworld.

The unlockable character Azazel evokes the biblical figure of Azazel. Azazel is only mentioned in Leviticus 16:8.10.26. The majority of the Old Testament exegetes interpret Azazel as a kind of demon, but there is no consensus about his origins: Azazel could be a nomadic, Egyptian, Anatolian, or Syrian demon (Van der Toorn et al. 1999, p. 129). What is clear, is that Azazel is related to the rite of Yom Kippur, when a sacrifice is made to effect reconciliation between God and men. The he-goat offered in sacrifice is not killed, however, but sent away into the desert, to Azazel.

Apollyon is the Greek name for the Hebrew Abaddon. In the Bible, the name Abaddon is used as a synonym of Sheol, i.e., the netherworld, in Proverbs 15:11; 27:20; Job 26:6, or of the grave in Psalm 88: 12. In Job 26:5-6, Abaddon seems to denote more than a place, namely a demon of deadly destruction (Van der Toorn et al. 1999, p. 1). Lilith is the name of a fearsome she-devil associated, in both Judaism and Christianity, with child abduction and involuntary nocturnal emissions (Bosman and Poorthuis 2015). 
The narratological level of the game seems to confirm the narratological levels of the prologue/epilogue and of McMillen's religious inspiration. Isaac is confronted with a theomanic mother figure who wants to kill him because she has heard a voice from on high commanding her to do so, which is a criticism of Abraham's blind obedience in the Genesis narrative. In both narratives, however, Isaac is rescued by "divine intervention". In Genesis, Abraham is the hero who is praised for his obedience by God's messenger, while in the game Isaac takes the role of the hero by triumphing over his crazy mother.

\subsection{The Post-Prologue/Epilogue Narratives}

The story of The Binding of Isaac could just have stopped here. McMillen would have made his main points: religion should be criticised for fostering blind obedience instead of critical thinking, and children especially risk becoming the primary victims of the religious zeal of their parents. In this perspective, religion appears as a form of legally and socially accepted child abuse. However, the prologue/epilogue and the game are only the first two of a total of four narratological layers.

As has been seen, both the prologue and epilogue have alternative endings, which we have so far ignored to avoid confusion. The prologue consists only of primitively hand-drawn pictures, probably done by Isaac himself. This intuition is fed by the real ending of the prologue, in which we see Isaac-in full colour instead of the black and white rendering of the previous drawings-as he laughs in the middle of his room. He holds a white sheet of paper in his hand, and he folds this before disappearing. We see other drawings hanging on his wall in the background. Again, a fly hovers before the camera.

The epilogue also has a kind of double ending. Initially, it seems that Isaac has defeated his mother by means of the Bible which falls on top of her. However, we then see Isaac again, depicted in full-colour, as he stands in his room, a fly hovering next to him. The door of his room is flung open and a silhouette appears in the doorway, resembling Isaac's mother, including a raised butcher's knife. The screen fades to black, without showing what happens next.

His "post-prologue" and "post-epilogue" deliver a new interpretive layer to BoI's narrative. Everything we have seen in the prologue/epilogue, including the game in between, seems to be the product of Isaac's imagination, as drawn on sheets of paper in his bedroom. Everything the player has encountered, including the hours of gameplay, could be reinterpreted as Isaac's psychological attempt to come to terms with an apparently abusive mother who wants to hurt him badly.

If this is indeed the case and it is true that everything stems from Isaac's imagination, then the whole idea of his mother's motivation for her abusive behaviour may also have been invented by Isaac. Confronted with an evil mother, Isaac looks for a rationale to understand—only up to a certain point of course-her behaviour towards him. As Isaac and his family are familiar with Christianity, Isaac may have chosen a biblical story, well known to him, that mirrors his own situation. By altering the traditional plot of the biblical "binding", a story that includes a "hero" with whom he shares his name, Isaac can construct a fantasy in which he not only provides a "sensible context" for his mother's behaviour, but also makes sure that he comes out on top.

This would mean that "the voice from above" his mother hears exists only in Isaac's fantasy, just as his own supposed sinfulness and the corresponding double punishment of the removal of his belongings and his isolation. Even the divine intervention, the Bible that falls on his mother's head, is an expression of Isaac's hope that his terrible situation will end in a satisfying way.

Seen in this light, BoI not only contains criticism of religion, but is also a psychological coping strategy in which Isaac tries to come to terms with living with an abusive mother. In this context, religion is not the cause of the abuse, but the narrative form in which the coping mechanism can take place. While the prologue/epilogue and the game itself appear to end with the victory of Isaac, the post-prologue and, especially, the epilogue seem to suggest the opposite: Isaac cannot stop his mother with his fantasies and is at his mother's mercy. Even though we are not shown what his mother does to him, we do not have to think long to understand that Isaac shares the fate of his Biblical name-giver, but without reprieve through divine intervention. 


\subsection{The Ending Narratives}

When the player has successfully defeated the Mother Monster in the game, he reaches the epilogue (and post-epilogue) discussed above. However, BoI is a game that strongly stimulates multiple playthroughs, thanks to the randomly generated dungeons and the high number of unlockables. Once the player has succeeded in beating the game again, twenty different endings can be found. These endings can be unlocked by defeating certain enemies who function as end bosses. Some endings provide ludological bonuses, e.g., passive items or unlockable characters (see Table 3).

Table 3. Various endings of The Binding of Isaac.

\begin{tabular}{|c|c|c|c|c|c|c|}
\hline Endings & Name & Source & Unlocked by & Description & & Effect \\
\hline Epilogue & Epilogue & $\mathrm{BoI} / \mathrm{BoR}$ & $\begin{array}{l}\text { Defeating Mom for } \\
\text { the 1st time. }\end{array}$ & Isaac's mother is struck down by a Bible. & & $<$ no effect $>$ \\
\hline 2 & Glue & BoI/BoR & Defeating Mom again. & $\begin{array}{l}\text { Isaac finds rubber cement in the chest, } \\
\text { uses it. }\end{array}$ & PI & Rubber cement \\
\hline 4 & Hanger & BoI/BoR & Defeating Mom again. & $\begin{array}{l}\text { Isaac finds a wire coat hanger, jams it } \\
\text { into his own head. }\end{array}$ & PI & Wire coat hanger \\
\hline 5 & Mother & $\mathrm{BoI} / \mathrm{BoR}$ & Defeating Mom again. & $\begin{array}{l}\text { Mother's arm reaches from inside the } \\
\text { chest, grabs Isaac. }\end{array}$ & A & $\begin{array}{l}\text { Everything is } \\
\text { terrible }\end{array}$ \\
\hline 8 & Quarter & $\mathrm{BoI} / \mathrm{BoR}$ & Defeating Mom again. & Isaac finds a quarter (coin) in the chest. & PI & Quarter \\
\hline 9 & Fetus & $\mathrm{BoI} / \mathrm{BoR}$ & Defeating Mom again. & $\begin{array}{l}\text { Isaac finds Dr. Fetus in the chest, } \\
\text { wearing top hat and monocle. }\end{array}$ & PI & Dr. Fetus \\
\hline 10 & ??? & $\mathrm{BoI} / \mathrm{BoR}$ & Defeating Mom again. & $\begin{array}{l}\text { Isaac finds ??? lying in the chest, who } \\
\text { sits up and smiles. }\end{array}$ & $\mathrm{UC}$ & $\begin{array}{l}\text { ??? (= unlockable } \\
\text { character) }\end{array}$ \\
\hline 11 & Heart & $\mathrm{BoI} / \mathrm{BoR}$ & Defeating Mom again. & $\begin{array}{l}\text { Isaac finds "It Lives" in the chest, } \\
\text { growling and smiling. }\end{array}$ & $\mathrm{UB}$ & It Lives \\
\hline 12 & Light & BoI/BoR & $\begin{array}{l}\text { Defeating Sheol } \\
\text { chapter. }\end{array}$ & $\begin{array}{l}\text { A bright light shines on Isaac from the } \\
\text { chest, switches to different characters, } \\
\text { Isaac steps into the chest. }\end{array}$ & $\cdots$ & $\cdots$ \\
\hline 16 & Crying & $\mathrm{BoI} / \mathrm{BoR}$ & $\begin{array}{l}\text { Defeating Mega } \\
\text { Satan. }\end{array}$ & $\begin{array}{l}\text { Isaac lies crying inside the chest, } \\
\text { assumes demon form. }\end{array}$ & $\cdots$ & $\cdots$ \\
\hline 17 & Skeleton & $\mathrm{BoA}$ & Defeating Hush. & $\begin{array}{l}\text { Ending } \# 15 \text {, mother opens chest, flies } \\
\text { and spiders, ghastly landscape, Isaac } \\
\text { pops out of red chest, large shadow } \\
\text { bends over him. }\end{array}$ & . & . \\
\hline 18 & Cave 1 & $\mathrm{BoA}$ & $\begin{array}{l}\text { Defeating Ultra Greed } \\
\text { in Greed Mode. }\end{array}$ & $\begin{array}{l}\text { Isaac is shown in a small cave, the } \\
\text { entrance collapses, rotting shopkeeper } \\
\text { who looks suddenly in the camera. }\end{array}$ & $\cdots$ & $\cdots$ \\
\hline 19 & Cave 2 & $\mathrm{BoA}+$ & $\begin{array}{l}\text { Defeating Ultra Greed } \\
\text { in Greedier Mode. }\end{array}$ & $\begin{array}{l}\text { As \#18, but the shopkeeper's head falls } \\
\text { off, spewing geyser of spiders. }\end{array}$ & $\cdots$ & $\cdots$ \\
\hline 20 & Final & $\mathrm{BoA}+$ & Defeating Delirium. & $\begin{array}{l}\text { A combination of multiple endings and } \\
\text { unique material. }\end{array}$ & . & $\cdots$ \\
\hline
\end{tabular}

Caption text: Overview of the endings in various versions of the Binding of Isaac, how to unlock them, and their ludological effects (see also Table 1): $\mathrm{A}=$ Achievement; PI = Passive item; UB = Unlockable boss; and $\mathrm{UC}=$ Unlockable character. <??? $>$ is the name of an unlockable character in the game. 
Narratologically, however, they provide numerous possible endings to Isaac's story, just as McMillen himself stated (2012). When all 21 endings are considered, including that of the (post-) epilogue, a new interpretation proposes itself concerning Isaac's "real story", even if major uncertainties have to be accepted. We examine them more closely below, while trying to fit them into the larger narrative of BoI.

Endings 1-11 present Isaac finding a chest, which he opens to find something (or someone) inside. Endings 12-20 present Isaac in different settings, some of which feature chests, while others do not. In the majority of cases, the ending represents danger to or death for Isaac, contrasting with the "happy" outcome of the main game and its epilogue.

Endings \#2 (glue) and \#7 (syringe) show Isaac picking up either rubber cement or a syringe from the chest, followed by a visibly deranged Isaac who is clearly under the influence of an intoxicating substance. Endings \#3 (noose) and \#4 (hanger) suggest either suicide or murder. We see Isaac hanged or with a twisted hanger driven through his head. The noose in ending \#3 is reminiscent of Judas (Iscariot), whom we also encountered earlier as an unlockable character. According to Matthew 27:3-10, Judas committed suicide by hanging himself after betraying Jesus. However, in contrast to Judas, the Isaac of the video game is not a traitor. He commits suicide-something he should not do.

It is remarkable that the player of the video game cannot see Isaac's face in the video game. He sees him from behind only. This implies that there is no possibility of face-to-face-contact. The way in which the child hangs in the noose is an expression of the impossibility of any communication. In this way, the Isaac of the video game is more like Abel than Judas Iscariot. In the version of Acts 1:18-19, however, Judas dies because his belly bursts open and his intestines fall out.

Ending \#5 (mother) is about a hand—seemingly Isaac's mother's—which comes from inside the chest, grabs Isaac, and pulls him in, while demonic laughter is heard. In the biblical narrative, the hand of Abraham plays a role in the slow motion just before the slaughter of Isaac. While Abraham's hand stretches out and grabs a knife, the hand in ending \#5, which must be Isaac's mother's hand, stretches out and grabs her son. While Abraham's hand is stayed, the mother's hand is not.

Ending \#6 (vomit) shows Isaac throwing up into the chest as he sees something inside it, followed by explosions, so that Isaac's fate remains unknown. Ending \#8 (quarter) is one of the few endings that produce a good outcome for Isaac: he is rewarded with a quarter (coin) that gives the player a financial head-start at the beginning of every run-through.

Endings \#18 (cave 1) and \#19 (cave 2) show Isaac getting trapped inside a cave because of falling rocks that block the only entrance. When the debris is cleared, apparently after a very long time, we see a zombie-like Isaac smiling at the camera. These two endings can be interpreted as a reverse Lazarus story (John 11:1-54). Whereas Lazarus is inside the grave, and the stone that closes the grave is removed so that he is able to come out, the child goes the opposite way: he enters the grave and is trapped inside by a multitude of stones at the entrance of the grave.

The Endings \#9 (foetus), \#10 (???) and \#11 (heart) are all connected to infanticide. While the "Dr. Fetus" from Ending \#9 is also a reference to McMillen's earlier game Super Meat Boy (McMillen 2010), the foetus-in-a-jar is a reference to abortion. In Ending \#10, Isaac finds a blue doll that resembles himself, with two crosses for eyes (just like the defeated mother from the epilogue). The blue colour could be a reference to "blue baby syndrome" that leads to cyanosis in infants because of heart failure. Ending \#11 shows Isaac looking into the chest only to see something that scares him terribly. Behind him a heart is shown in the form of Isaac himself, shouting loudly. The music played while defeating this unlocked boss (dubbed "It Lives" in the game) is called "ventricide", a made-up word denoting either "killing of the heart" (English "ventricle" + Latin caedo, "to kill") or "killing of the womb" (Latin ventus, "womb" + caedo).

In Ending \#12 (light), Cain, Mary Magdalene, Judas Iscariot, Eve, and Azazel appear (all unlockable characters). The Isaac of the video game is placed in the company of these "bad guys", these "losers" in the biblical narratives. He joins them voluntary. The décor in which the Old Testament figures of Cain and Eve appear consists of large intestines. Are they a reference to the 
intestines of the big fish in which Jonah stayed for three days and nights? Jonah experienced a rebirth by emerging from the fish's intestines. This could imply that joining the group of unlockable characters is a form of rebirth for the Isaac of the video game too.

Ending \#13 (Bible) sticks to the Biblical setting. Isaac reads the Bible and looks into a mirror. Mirrors are rarely mentioned in the Bible. 1 Cor 13:12 uses the image of a mirror to explain that we cannot yet see the final salvation because we currently see in the dark, but that, when salvation will be fully realised, we will no longer see any vague reflection, but salvation itself. The child appears to gain some kind of knowledge or insight from reading the Bible. The insight in question could be two things. (1) Isaac comes to think in the same way his mother does, implying consent to being sacrificed. The devilish version of himself in the mirror perhaps points to this interpretation. Isaac agrees with his mother that he is sinful and must be sacrificed, thus mixing his mother's first two "motivations" in the prologue with the third one (proof of loyalty to God). (2) Isaac believes the exact opposite: he disagrees with his mother, which in fact would be in accordance with the biblical story in Genesis 22:1-19. The ending gives no clues as to which option it is. The simple fact of reading the Bible does not in itself give any information about someone's faith. It is not about the act reading the Bible as such, but about how the act of reading the Bible is performed.

Ending \#16 (crying) also incorporates a kind of self-identification of Isaac. Isaac is lying in the chest, again in a foetal position, just as in the epilogue. He is crying silently, but his breathing becomes louder, indicating a lack of oxygen in the chest. Then, he is changed into a demon, who smiles frantically into the camera.

Endings \#15 (missing) and \#17 (skeleton) both indicate that Isaac has run away from home, \#17 that Isaac has hidden himself in the chest in his room. In \#15, we see a missing persons poster nailed to a pole beside Isaac's house. Isaac's mother can be seen standing on the other side, apparently looking for her son. After the missing persons poster of Ending \#15, in \#17 we see an unknown figure, probably Isaac's mother, opening the chest and finding Isaac's bones, covered in cobwebs, indicating that he has been there for a very long time. Ending \#17 continues with Isaac opening the chest in an unknown, ghoulish, grey countryside. His shadow grows into a vampire-like figure that screeches at Isaac.

Without a doubt, the most insightful endings are Endings \#14 (pictures) and \#20 (final). Both endings feature polaroid pictures with their distinctive white passe-partout. In Ending \#14 we see a stack of pictures disappearing in the distance, with a typical dungeon from the game in the background, although there is nothing in it. The fact that the pictures disappear makes it increasingly difficult to see the details of the subsequent pictures. We see the following scenes. (a) Mother, Isaac (fully dressed) and a male figure, probably Isaac's father, who is not seen or heard anywhere else in the game. (b) Isaac's mother with an unknown female child, who is not seen or heard anywhere else in the game either.

(c) A naked Isaac in his room with a devilish, dark figure in the corner in the back, who resembles Isaac's silhouette with the hanger through his head (Ending \#4). (d) Isaac's mother and father smiling at each other as they hold hands. (e) Isaac (dressed) outside, alone. (f) A naked Isaac crying, sitting beside a closed chest. (g) Isaac's mother holding a knife in her hand as she did in the prologue, epilogue, and post-epilogue. However, we cannot see who she is threatening with the knife: Isaac, Isaac's father/her husband, or someone else? (h) Isaac and his mother look through a window at an unidentified person outside, perhaps his father. (i) The text "the end" appears.

The final Ending \#20 is the most elaborate, in which various other endings re-appear and are recontextualised. We see the following scenes. (a) A naked Isaac lies in a chest, breathing heavily (cf. Ending \#16). (b) A naked Isaac smiles as he draws pictures in his room, but he is interrupted by the sound of two people having a violent argument, probably his parents. (c) A drawing of Isaac's home (cf. prologue) with the words "we lived here". The past tense is intriguing. (d) A naked Isaac in a chest, now crying silently (cf. Ending \#16). (e) Isaac, himself unseen, sees his mother weeping silently in front of a television (switched off) as she sits on the couch (cf. prologue). (f) Isaac is still in his chest crying, his breathing becomes heavier (cf. Ending \#16). 
(g) Isaac holds a polaroid picture (cf. Ending \#14) of himself and his mother and father, but the father has been burned out. There is a chest full of other half-burned polaroids in the background. We see various pictures drawn by Isaac on the wall of Isaac's room: a chest, their house, a cat, Mary Magdalene (perhaps his unseen sister; cf. Ending \#12), and Isaac with devil's horns, including an arrow pointing to him with the word "me" (cf. Ending \#16). (h) Isaac in the chest once again, turning blue (cf. Ending \#10).

(i) A wall full of polaroids and drawings. The polaroids show the following scenes: Isaac together with his mother and father, and Isaac with his mother (cf. Ending \#14). The drawings are of the following things: Isaac's home; Isaac with a cat; Isaac playing with his father; Isaac witnessing a fight between his parents; Magdalene/his sister having fun; Isaac's mother with a knife looking very angry; two drawings of Isaac as a devil/vampire (cf. Ending \#17), with the words "me", "bad", and "I am the devil"; a pentagram with the word "bad"; and Isaac and his mother lying dead in their own blood, with a black devil/vampire standing on Isaac's body.

(j) Isaac's skeleton lying in the chest, with cobwebs. The chest is opened by an unknown person, probably his mother (cf. Ending \#17). (k) Isaac's home with a withered wanted poster on the pole (cf. Ending \#15), eventually blown away by the wind. (l) After a fade-out and a fade-in, we see Isaac's silhouette in a ghoulish grey countryside (cf. Ending \#17), as it walks away into the horizon.

The various endings, especially Endings \#14 (pictures) and \#20 (final), permit us to reconstruct Isaac's "true" story, although many uncertainties remain. Isaac lives happily with his father and mother in their "house on the hill", until Isaac's parents experience marriage problems. These family problems may be connected to the "missing" female character in the pictures, present in-game as the unlockable character Magdalena, probably Isaac's sister who seems to have vanished. Perhaps Isaac's sister died, putting an enormous strain on the relationship between her parents.

The fights between Isaac's parents intensify, until something happens that provokes Isaac's mother to force her husband/Isaac's father out of their home by wielding a kitchen knife. The father walks out of their lives, seemingly never to return again. Isaac's mother is-understandably—very sad about the separation (which may or may not have resulted in a civil divorce), and her son Isaac sees her in her sorrow, and blames himself for the situation (as happens from time to time with children of divorced parents).

Isaac, having been brought up in a Christian context, tries to find a familiar form or narrative that can help him cope with his mother's sadness, the divorce between his parents, and his self-blaming. He chooses the Biblical story from Genesis, probably because of the similarity in name: Isaac. Mixing reality and childish fantasy, Isaac comes up with a story in which he is punished by his theomanic mother who believes she is acting out God's will to purify her corrupt/sinful son.

Eventually, Isaac manages to hide permanently from his mother, whom he now regards as violent towards him. Even though his mother tries to find her lost son, she does not find him soon enough to prevent him suffocating in his toy chest. Then, Isaac walks the plains of the afterlife, leaving behind his parents in sorrow and with countless questions. We could even imagine that, while the divorce between his father and mother triggered Isaac's self-blaming, the death of their child causes them even more stress, perhaps leading them to blame themselves for the death of their child.

\section{Interpretations: Constructing the Story}

After examining the pre-text, the (post-)prologue, and epilogue, the game itself, and the various endings of The Binding of Isaac, we are now able to establish three different interpretive layers, each new layer building on the one below it.

Initially, when we look exclusively at the prologue/epilogue and the game itself, we see a narrative that is critical of religion. Borrowing from the infamous story from Genesis about a father who is prepared to sacrifice his only son "just" to prove his loyalty to his God, The Binding of Isaac presents a story about a theomanic mother who gives up her rationality and mother's instinct in blind obedience to an entity whose existence is probably imaginary. BoI can be read as a variation on Dawkins's point 
quoted above that these kinds of absurd Biblical stories stand at the source of the three monotheistic faiths, "proving" their inherent violent and intolerant nature. Fortunately enough-in the eyes of the critics-the modern-day Isaac triumphs over his mother's madness and survives the attack.

However, two points continue to puzzle in this interpretation. First, this critical interpretation ignores the actual outcome of the Biblical narrative, in which Isaac is saved too. Second, in both narratives "salvation" comes from divine intervention, in the form of a voice or of a falling Bible. The modern-day Isaac survives his crazy mother not because he uses his wits or rational thinking to combat her superstition, but because of a deus ex machina, which is exactly the kind of thinking Dawkins cum suis opposes. Following this interpretation, the intertextual relationship between the arche- and feno-texts should be qualified as a destructive one (Kristeva 1980).

However, second, this simplistic religion-critical interpretation is challenged by the post-prologue and post-epilogue in which it is substituted by the idea of religion as a coping mechanism. Isaac, confronted with an abusive mother, whose motivations are unclear for the moment, develops an imaginative story or context which he uses to successfully interpret his mother's behaviour, including a "rational" motivation. Borrowing from a familiar source, the Bible, specifically from a narrative that suits him well, the Genesis narrative about Abraham and Isaac, the child constructs an alternative reality in which he is the victim of his mother's theomania.

Isaac provides his mother with an excuse for her violence against him: she hears "voices" in her head, commanding her to do the things she does. The reality of the game itself provides a narratological context for Isaac in which he is able to actually fight against this reimagining of his mother in order to claim psychological victory over the evil that haunts him. Thus, Isaac is able to excuse his mother emotionally while securing his own survival in the process.

This interpretation renders the real ending of the story unsure, but the image of Isaac's mother standing in his doorway with a knife in her hand, the figure over whom Isaac had just triumphed with the help of divine intervention, relentlessly points to a disastrous ending for Isaac. His religiously inspired fantasy may have soothed him psychologically, but cannot prevent his mother from murdering him in the end.

The intertextual relationship between arche- and feno-text now becomes more complex, shifting from a one-dimensional destructive one to a more constructive relationship. The mother is certainly crazy, but she is no longer theomanic, just "normally" homicidal towards her son. The criticism shifts from religion to child abuse. The salvation that comes to Isaac in Genesis and in the epilogue of BoI is welcomed as positive, if ultimately unavailing.

Here, it is worth reflecting on the role of Abraham incorporated from the arche-text into the feno-text. In the video game, the main character is played by Isaac, as is common in the Jewish reception of the Genesis text. The role of Abraham is first of all played by the mother in the video game. She is the one who approaches the child with a knife, according to a voice, expressed by a Bible falling down. This shift in gender emphasizes that child abuse is not a male thing, but could be done by any adult, irrespective of his/her gender. In the arche-text, sonship is at issue: the father should have a male successor in order to continue the family tree. The Abraham of Genesis has to resolve many problems to get such a successor with his legal wife. Genesis 22:1-19 triggers this problem to focus on the male characters Abraham and Isaac. Because this family line is not an issue in the video game, the male gender is not important. To make this clear, the role of Abraham is played by the mother character. Regarding Isaac, it is important to notice that, in his form of a pink young child, he is gender-neutral. Only when his clothes are taken away, Isaac is recognizable as a boy.

However, the role of Abraham is not only played by the mother character. In the arche-text, it is Abraham who spares Isaac by not sacrificing him, but a ram instead. It is, as it were, also Abraham who has to "save" Isaac in the biblical story. In the video game, the mother can hardly be described as the one who saves her child Isaac. If a game-Abraham should be identified, it is Isaac's absent father, but he only appears on the third, not on the second narratological level. Besides, on the third level, where Isaac's father briefly appears, he does not save his son, he just leaves. 
One could argue that, on the second narratological level, it is the player of the video game who has this task. By playing the video game, the player becomes Abraham. If he fails, Isaac will be dead, just as, in the Genesis narrative, Isaac would be dead if Abraham had eventually failed. If the player is successful, Isaac will be saved, even if the player does not understand all the aspects of meaning hidden in the video games, as the role of Abraham in the Genesis narrative could be interpreted as performed by someone who does entirely understand what happens. However, again, as soon as we incorporate the next interpretative level, the identification between the player and the Biblical Abraham becomes problematic.

On the third and last interpretative level, that of the game's multiple endings, especially Endings \#14 and \#20, the criticism of religion is minimised, and maximum emphasis is placed on (unintentional!) child abuse in the form of a violent divorce. Isaac's parents' divorce upsets his psychological balance, especially since he witnessed the physical threat his mother posed to his father, his father's desertion of him, and his mother's unbearable sadness afterwards. Isaac starts to blame himself for the divorce and the violence, seeing himself more and more as a sinner and as a devil who is destined to die, to be murdered, or to commit suicide to prevent worse.

The (unjustified) view that Isaac is possessed by a demon does not stem from the Isaac narrative, but probably from other passages in the Old and New Testament. Isaac identifies with other "sinners" in the Bible, who must on the one hand be regarded as sinners, but who must on the other hand be pitied as victims of circumstances they could not control, like Eve or Judas. The criticism of religion is mild, as the text is not extensively debated, but the dark interpretation readers of the Bible can produce, including darkening self-defamations.

The intertextual relationship changes from a destructive/constructive one to a deconstructive one, in which arche- and feno-texts mutually interpret each other. This is exactly what McMillen wanted to present with his game, especially with the multiple endings: to encourage players to have multiple interpretation of his work. Moreover, the BoI game-in all its harshness and violence-asks serious questions about uncritical receptions of Biblical narratives, and about all forms of child abuse, especially those stemming from religion itself, or from family crises like divorce and violence.

In theology, the discussions on Genesis 22:1-19 are ongoing. Our analysis has made clear that BoI as a video game could offer an important contribution to these discussions with interpreting the Binding of Isaac/Abraham's sacrifice as a model of disobedience (Boehm 2007): a protest against child abuse, religiously justified. The Binding of Isaac stands in the interpretative tradition of reading the story of Isaac as a protest against child sacrifices, placing the Isaac's story in a postmodern context of divorce, family troubles and (non-sexual) child abuse. Theologically, the games equates "sacrifice" with "abuse". Both actions are executed by a parent, although in both cases an external force is manipulating them, easing the moral pressure on the parents.

In Genesis, the external force is identified as God, while in BoI it is either the mother's theomania (narrartological level 1 and 2) or mental imbalance caused by a traumatic divorce and/or disappearing of unknown daughter/sister, who could have ended up living with her father, thus tearing up the family even further (level 3). In the first case, Isaac's mother is morally excused because of her mental condition. In the second case the whole "abuse" is not deliberately or actively caused by his mother, but by a very unfortunate mixture of circumstances.

The position of God in this theological interpretation is ambiguous: either He is very involved in the development of the story, as a voice from above (to the mother) or as intervener smashing the Bible on the mother's head and saving Isaac at the end (narratological level 1), or he is painfully absent, existing only in Isaac's mind while trying to psychologically cope with his troubled family problems (levels 2 and 3). God does not play a visible role in the ending narratives, nor seems there to be a "happy ending" for Isaac in anyone of them. The abuse is criticized, but not solved.

Author Contributions: Frank G. Bosman and Archibald L. H. M. van Wieringen conceived and designed the experiments; Frank G. Bosman performed the experiments; Frank G. Bosman and Archibald L.H.M. van Wieringen analyzed the data; Frank G. Bosman and Archibald L.H.M. van Wieringen wrote the paper. 
Conflicts of Interest: The authors declare no conflict of interest.

\section{References and Note}

All biblical quotes are taken from the Revised Standard Version.

Agus, Aharon R. E. 1988. The Binding of Isaac and Messiah: Law, Martyrdom and Deliverance in Early Rabbinic Religiosity. Albany: State University of New York Press.

Bauer, Dieter. 2017. Ein Gott, der verlangt, dass wir unsere Kinder opfern? Die Erprobung Abrahams (Genesis 22). Bibel Heute 53: 16-17.

Boehm, Omri. 2007. The Binding of Isaac: A Religious Model of Disobedience (The Library of Hebrew Bible/Old Testament Studies 468). New York and London: T \& T Clark.

Bosman, Frank. 2016. The Word Has Become Game: Researching Religion in Digital Games. Online. Heidelberg Journal of Religions on the Internet 11: 28-45.

Bosman, Frank, and Marcel Poorthuis. 2015. Nephilim: The Children of Lilith. The Place of Man in the Ontological and Cosmological Dualism of the Diablo, Darksiders and Devil May Cry Game Series. Online-Heidelberg Journal of Religions on the Internet 7: 17-40.

Caspi, Mishael, and John Greene, eds. 2007. Unbinding the Binding of Isaac. Lanham: University Press of America. Dawkins, Richard. 2006. The God Delusion. London: Bantam Press.

Heidbrink, Simone, Tobias Knoll, and Jan Wysocki. 2015. Venturing into the Unknown (?) Method(olog)ical Reflections on Religion and Digital Games, Gamers and Gaming. Online. Heidelberg Journal of Religions on the Internet 7: 68-71.

Holmes, Jonathan. 2011. How a Killer Christian Shmup Roguelike Came to Steam. Destructoid. July 21. Available online: https: / www.destructoid.com/how-a-killer-christian-shmup-roguelike-came-to-steam206601.phtml (accessed on 13 February 2018).

Jagielski, Rachel. 2011. The Binding of Isaac: Interview with Team Meat's Edmund McMillen. Venturebeat. September 2. Available online: https:/ /venturebeat.com/community/2011/09/02/interview-with-teammeats-edmund-mcmillen (accessed on 13 February 2018).

Kristeva, Julia. 1980. Desire in Language: A Semiotic Approach to Literature and Art. Edited by Leon Roudiez. New York: Columbia University Press.

Lenzen, Verena. 2003. Das Opfer von Abraham, Isaak und Sara. Genesis 22 im rabbinischen Judentum. Welt und Umwelt der Bibel 30: 13-17.

McMillen, Edmund. 2010. Super Meat Boy. Asheville: Team Meat, Digital game.

McMillen, Edmund. 2011. The Binding of Isaac, Edmund McMillen. Digital game.

McMillen, Edmund. 2012. Postmortem: McMillen and Himsl's The Binding of Isaac. Gamasutra. November 28. Available online: https:/ / www.gamasutra.com/view / feature/182380/postmortem_mcmillen_and_himsls_ .php (accessed on 13 February 2018).

McMillen, Edmund. 2014. The Binding of Isaac. Rebirth. Santra Ana: Nicalis, Digital game.

McMillen, Edmund. 2015a. The Binding of Isaac. Afterbirth. Santra Ana: Nicalis, Expansion pack.

McMillen, Edmund. 2015b. The Binding of Isaac. Afterbirth+. Santra Ana: Nicalis, Expansion pack.

Rowley, Matthew. 2015. Irrational violence? Reconsidering the logic of obedience in Genesis 22. Themelios 40: 78-89.

Smith, Ewan. 2011. New Details on Team Meat Designer's New Game. IGN. July 12. Available online: http:/ / www. ign.com/articles/2011/07/12/new-details-on-team-meat-designers-new-game (accessed on 13 February 2018).

Tischler, Nancy M. 2009. Thematic Guide to Biblical Literature. Westport and London: Greenwood Press.

Van der Toorn, Karel, Bob Becking, and Pieter W. van der Horst, eds. 1999. Dictionary of Deities and Demons in the Bible. Leiden: Brill.

Van Wieringen, Archibald L. H. M. 1995. The Reader in Genesis 22:1-19: Textsyntax-Textsemantics—Textpragmatics. Estudios Bíblicos 53: 289-304.

Westermann, Claus. 1981. Genesis (BKAT 1/2). Neukirchen-Vluyn: Neukirchener Verlag.

(C) 2018 by the authors. Licensee MDPI, Basel, Switzerland. This article is an open access article distributed under the terms and conditions of the Creative Commons Attribution (CC BY) license (http:/ / creativecommons.org/licenses/by/4.0/). 